\title{
ANALYSIS OF COMPOUNDS AND IMMUNOSTIMULATORY PROPERTIES OF CURCUMA MANGGA RHIZOMES ON MALE MICE
}

\author{
Yuandani ${ }^{1,2, *}$, S. Yuliasmi ${ }^{3}$ and D. Satria ${ }^{4}$ \\ ${ }^{1}$ Department of Pharmacology, Faculty of Pharmacy, Universitas Sumatera Utara, 5 Jalan Tri \\ Dharma, USU-Kampus, Medan 20155, Indonesia, \\ ${ }^{2}$ Centre of Excellence for Green Chitosan and Advanced Materials, Universitas Sumatera Utara, \\ Medan 20155, Indonesia \\ ${ }^{3}$ Department of Pharmaceutical Chemistry, Faculty of Pharmacy, Universitas Sumatera Utara, 5 \\ Jalan Tri Dharma, USU-Kampus, Medan 20155, Indonesia \\ ${ }^{4}$ Department of Pharmaceutical Biology, Faculty of Pharmacy, Universitas Sumatera Utara, 5 \\ Jalan Tri Dharma, USU-Kampus, Medan 20155, Indonesia \\ *E-mail: yuan_dani@yahoo.com,yuandani@usu.ac.id
}

\begin{abstract}
The current study was carried out to determine the constituents in ethanol extract of Curcuma mangga rhizomes and its immunostimulatory effects of the extract on cellular and humoral immunity of male mice. Determination of constituents in the extract was conducted using Ultra Performance Liquid Chromatography. The ethanol extract of Curcuma mangga was comprised to delayed-type hypersensitivity response and haemagglutinating antibody titre tests for its immunostimulatory potential. The test animal received extract at doses of 100, $200 \mathrm{and} 400 \mathrm{mg} / \mathrm{kg} \mathrm{BW}$ for 7 days after sensitized by bovine Red Blood Cells. Cellular response was measured by increase of paw volume, meanwhile humoral antibody response was determined by hemagglutination method. Quercetin was determined quantitatively in the extract by a validated reversed phase Ultra Performance Liquid Chromatography method. The footpad thickness and antibody titre of male mice after treatment with ethanol extract of Curcuma mangga were significantly higher as compared to negative control $(\mathrm{P}<0.05)$. The extract of Curcuma mangga at a dose of 400 $\mathrm{mg} / \mathrm{kg} \mathrm{BW}$ depicted stronger immnumostimulatory activity as compared to positive control. The result indicates that the ethanol extract of Curcuma mangga shows immunostimulatory activity, emphasizing its potential to be developed as a therapeutic agent.
\end{abstract}

Keywords: Curcuma mangga, immunostimulatory, delayed-type hypersensitivity, antibody titre, quercetin

(c) RASĀYAN. All rights reserved

\section{INTRODUCTION}

Human immune defense consists of two main categories which include innatae (non-specific) and adaptive (specific) immunity ${ }^{1}$. Adaptive immunity is different from the innate response as it is specific due to the presence of an element of memory. The humoral component of acquired immunity mainly is antibody-secreting plasma cells from the proliferation of antigen-stimulated B lymphocytes. The cellular immunity (also called: cell-mediated immunity (CMI) is primarily facilitated by thymus-derived small lymphocytes (T cells), which can be divided into T helper cells (Th) and cytotoxic T lymphocytes (Tc) ${ }^{2}$. Th lymphocytes play an essential role in immune response because they maximize the ability of the immune response by performing several functions, such as activating phagocytes by producing interferon gamma (IFN $\gamma$ ), stimulating $\mathrm{T}$ cytotoxic cells and increase the activity of natural killer (NK) cells. In addition, $\mathrm{T}$ helper cells activate $\mathrm{B}$ cells to secrete antibodies (immunoglobulins). Thereafter, immunoglobulins circulate in the lymph and the blood streams, bind to the antigens to enhance destruction by phagocytes ${ }^{3}$. A number of diseases can be treated by immune response modifiers; these include immunodeficiencies and autoimmune diseases like systemic lupus erythematosus and rheumatoid 
arthritis ${ }^{4}$. Immunomodulators are used to suppress or increase host immune responses in the treatment of those diseases ${ }^{5}$. Nowadays, there has been a big trend toward using natural products as immunomodulators ${ }^{2}$.

The plants of family Zingiberaceae have been used in folk medicine ${ }^{6}$. Curcuma mangga is one of them which has been used to treat many ailments such as cancer, fever, and stomach disorders ${ }^{7}$. Previous studies have shown a wide array of biological activities of $C$. mangga, including antifungal, analgesic, anticancer, anti-inflammatory, antioxidant and nitric oxide inhibitory activities ${ }^{8-10}$. Curcuma mangga was found to contain various organic compounds, including polyphenols, flavonoids, triterpenes and sterols. This plant was reported to have curcuminoid as its major components, these include curcumin, demethoxycurcumin and bisdemethoxycurcumin ${ }^{7,11}$. Others secondary metabolites may contribute to the pharmacological activity of $C$. mangga. Flavonoids have been reported to enhance the proliferation of lymphocyte ${ }^{12}$. Quercetin is in the class of flavonoids which has been reported to have antioxidant activity $^{13}$. Our in vivo study reported that $C$. mangga increased phagocytosis ability of mice leukocytes ${ }^{14}$. However, it is necessary to elaborate its immunomodulatory activity on adaptive immunity. The current study was conducted to investigate the constituents in ethanol extract of $C$. mangga and its effects of on Delayed Type Hypersensitivity (DTH) response and antibody titres of male mice.

\section{EXPERIMENTAL}

\section{Materials}

Several chemicals were used in this study, such as ethanol (SmartLab, Indonesia), Phosphate-buffered saline (PBS) (Sigma, USA), natrium carboxylmethlcellulose (Na CMC) (Sigma, USA) and levamisole (askamex®) (Soho, Indonesia). Quercetin (Sigma, USA) was used as a reference standard. A plestimometer (Shimadzu, Japan) and rotary evaporator (Heidolph VV-300, Germany) was also used in this study. Constituents determination was performed using Ultra Performance Liquid Chromatography (UPLC) from Agilent Technologies (US). Acetonitrile and methanol HPLC grade from Merck (US) were used to perform the UPLC analysis.

\section{Plant Collection}

The $C$. mangga rhizomes were collected from Medan, Sumatera Utara, Indonesia. Then, the plant was identified in Herbarium Medanense (MEDA), Universitas Sumatera Utara, Indonesia.

\section{Extraction Procedure}

The rhizomes materials were washed and dried to obtain simplicia. An amount of $500 \mathrm{~g}$ simplicia was ground and extracted with maceration method. Ethanol was used as a solvent, at the ratio of sample: solvent was 1:10 (w/v). The residue was macerated twice, then the filtrate was combined. The extract of C. mangga was obtained after removing the solvent using a rotary evaporator to yield $38.4 \mathrm{~g}, 10.95 \%$ w/w.

\section{UPLC Quantitative Analysis of the Ethanol Extract of Curcuma mangga}

Determination of constituents in $C$. mangga extract was performed using reversed-phase UPLC by the modified method of Ang et al. (2014) ${ }^{15}$. The extract and quercetin as a standard were prepared in methanol with a concentration of 20 and $1 \mathrm{mg} / \mathrm{mL}$, respectively. Thereafter, the sample and standard compound were filtered using PTFE membrane $(0.45 \mu \mathrm{m})$ and subjected to C-18 column Eclipse Plus $(100 \mathrm{~mm} \times 4.6 \mathrm{~mm}$ i.d., $3.5 \mu \mathrm{m})$ using mobile phase which consist of acetonitrile (A) and water (B) and eluted isocratically with $40 \% \mathrm{~A}$ and $60 \% \mathrm{~B}$ for $5 \mathrm{~min}$ at a flow rate of $1.3 \mathrm{~mL} / \mathrm{min}$ with DAD as a detector, at wavelength of $370 \mathrm{~nm}$. Qualitative analysis was performed by comparing the spectra and retention time of the peak extract and those of the standard. Meanwhile, the compound in the extract was quantified by plotting calibration curves of quercetin as a standard with six concentrations ranging from $100,50,25,12.5,6.25$ and $3.125 \mu \mathrm{g} / \mathrm{mL}$. The method was validated by determining linearity, precision, limits of quantification (LOQ) and detection (LOD) as reported by the previous study ${ }^{16}$. The precision of the method was determined by inter-assay and intra-assay validation. The correlation coefficient (r2) 
indicated the linearity. LOQ and LOD were calculated from the relative standard deviation (RSD) and slope (S) of the calibration curves by the following the formula:

$$
\begin{aligned}
& \mathrm{LOD}=3.3 \times(\mathrm{RSD} / \mathrm{S}) \\
& \mathrm{LOQ}=10 \times(\mathrm{RSD} / \mathrm{S})
\end{aligned}
$$

\section{Delayed-Type Hypersensitivity (DTH) Response}

The effect of the extract on DTH response was evaluated by the significantly decrease or increase in paw volume following modified method of Mubashir et al. (2013) ${ }^{17}$. Prior to treatment with extract, mice were subcutaneously injected in hind foot pad with $1 \%$ in PBS of bovine RBCs for sensitization. Then, the animals received $C$. mangga extract at doses of $100,200,400 \mathrm{mg} / \mathrm{kg}$ BW for 7 days. The animals in the negative control group were treated with vehicle (Na CMC $0.5 \%$ ) only. The positive control used in this study was levamisole $(25 \mathrm{mg} / \mathrm{kg} \mathrm{BW})$. On day 7 , the volume of paw mice was measured by plestimometer, then, all the animals were challenged by a subcutaneous injection of the same amount of bovine RBCs in the hind footpad. The cellular mediated immunity was measured at 24 hours later on day 8 in terms of increase in paw volume. The DTH response was expressed by the mean increase of paw volume. The approval to use animal was obtained from the Animal Research Ethics Committees of Universitas Sumatera Utara (approval number 581/I(EPH-FMIPA/20I7).

\section{Haemagglutinating Antibody Titre (HAT)}

The effect of the extract on humoral antibody response was evaluated by hemagglutination antibody titre method as described previously with slight modification ${ }^{17}$. Prior to treatment with extract, mice were injected by bovine RBCs for immunization. Then, the animals received $C$. mangga extract at doses of $100,200,400 \mathrm{mg} / \mathrm{kg} \mathrm{BW}$ for 7 days. The animals in the negative control group were treated with vehicle (Na CMC $0.5 \%)$ only. The positive control used in this study was levamisole $(25 \mathrm{mg} / \mathrm{kg} \mathrm{BW}$ ). On day 7 , blood samples were collected in microliter tubes from vein tail for HA titre determination. The blood samples were centrifuged and the serum was separated. The titre was determined by titrating serum dilutions with bovine RBCs. Haemagglutination was observed visually. Mean log of antibody titre [2(log titre) +1$]$ was calculated to compare the results.

\section{Statistical Analysis}

The SPSS version 15.0 was used for data analysis using a one-way analysis of variance (ANOVA) and followed by Tukey post hoc test with $\mathrm{P}<0.05$ as consideration of different significantly.

\section{RESULTS AND DISCUSSION \\ UPLC Quantitative Analysis of the Ethanol Extract of $C$. mangga by UPLC}

Curcuma species has been well studied to have curcuminoid as its major constituents ${ }^{7,11}$. However, others secondary metabolites may present in $C$. mangga and contribute to its pharmacological activity. Therefore this study may give new insight into the knowledge. This study found that $C$. mangga rhizomes contained a low amount of quercetin UPLC reversed-phase method. The chromatogram of the ethanol extract of $C$. mangga showed a peak of quercetin with retention times at $1.57 \mathrm{~min}$. The peak was compared to reference standards of quercetin with retention times at $1.59 \mathrm{~min}$ (Fig.-1). Quantification analysis showed the amount of quercetin as $3.73 \mu \mathrm{g} / \mathrm{mL}$. Correlation coefficient ( $\mathrm{r} 2)$ of 0.9910 was obtained with the concentration range of $100-6.25 \mu \mathrm{g} / \mathrm{mL}$. The $\%$ RSD values for interday assay precision of peak area and retention time for quercetin were 6.23 and $0.32 \%$ respectively. Whereas the $\%$ RSD values for the intraassay precision of peak area and retention time for quercetin were 0.74 and $0.47 \%$ respectively. These values demonstrated the reproducibility of the results. Limit of detection (LOD) and limit of quantification (LOQ) were found to be 0.32 and $0.96 \mu \mathrm{g} / \mathrm{mL}$, respectively.

\section{Delayed-Type Hypersensitivity (DTH) Response}

Delayed-type hypersensitivity (DTH) response is a cellular immune response which facilitated by activation of $\mathrm{T}$ lymphocytes and followed by releasing cytokines. In turn, cytokines activate 
macrophages to initiate inflammation (defensive) response which is indicated by paw edema formation ${ }^{18-}$ ${ }^{19}$. The activity of $C$. mangga extracts on DTH response of mice was evaluated by paw volume. The enhanced of paw edema formation indicates the increment of DTH response of mice immune cells. The stimulation of cellular mediated immunity of $C$. mangga was in a dose-dependent manner.

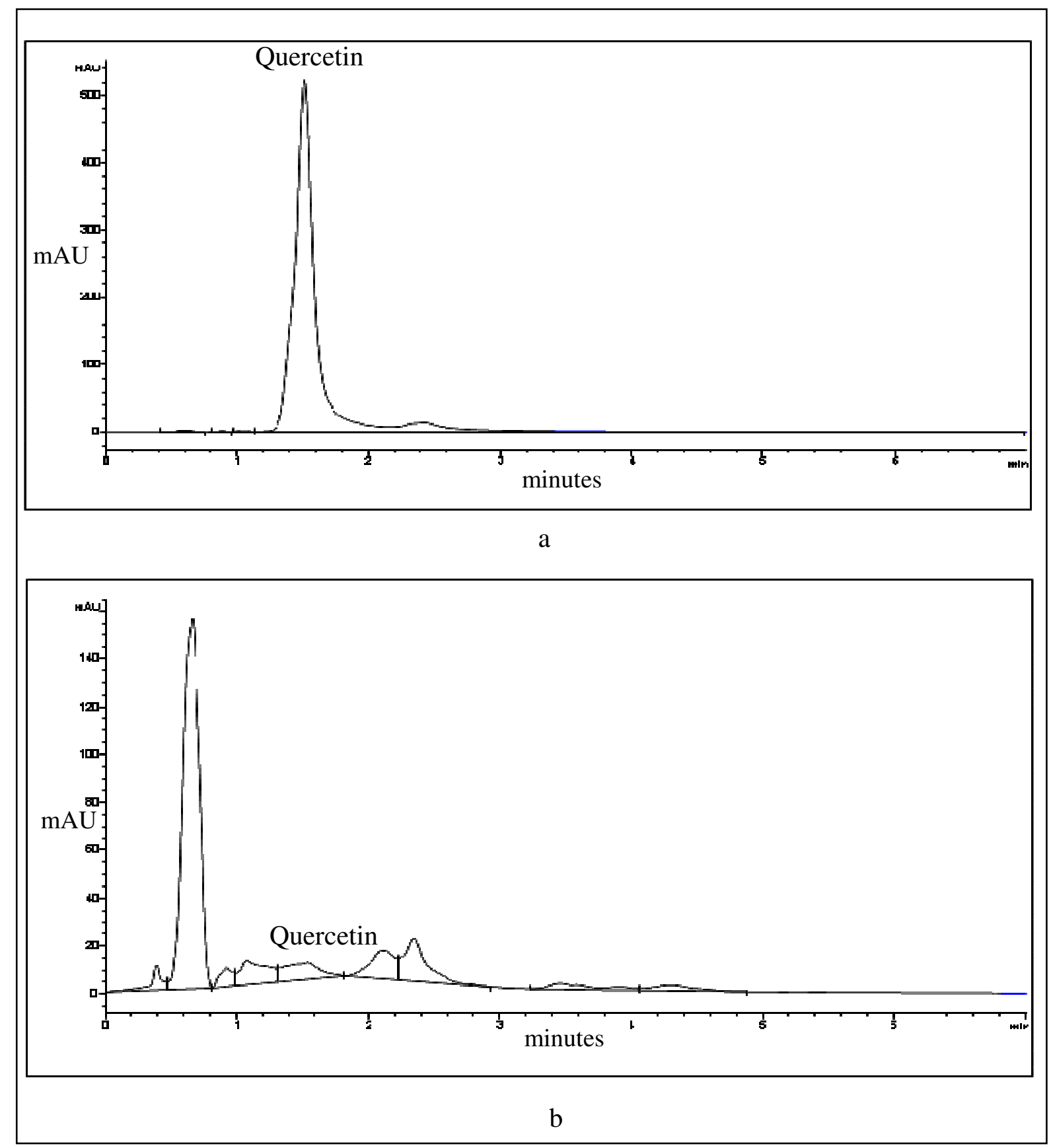

Fig.-1: Representative UPLC chromatograms of (a) quercetin, RT 1.59 min (b) Curcuma mangga ethanol extract detected at the wavelength of $370 \mathrm{~nm}$

The footpad thickness $(\Delta \mathrm{V})$ after treatment with various doses of $C$. mangga extract was higher as compared to negative control $(\mathrm{P}<0.05)($ Table-1). The results indicate that the extract was increasing the DTH response and thus stimulating cell mediated immunity. Of all the sample, the $C$. mangga extract at a dose of $400 \mathrm{mg} / \mathrm{kg} \mathrm{BW}$ showed the strongest stimulant which was comparable than those of positive 
control, Levamisole. Levamisole was used as a positive control. The result was in accordance with the previous study which showed the ability of $C$. mangga methanol extract to increase the phagocytosis response by in vitro and in vivo study ${ }^{14,20}$.

\section{Humoral Antibody Titre}

The antibody titre was determined to evaluate the humoral response against bovine RBCs. Humoral responses result in the production of proteins, known as antibody reactive with a particular antigen. Levels of antibody in serum can be determined as antibody titres. The antibody was cross-linked with red blood cells leading to agglutination ${ }^{14}$. Antibody titres expressed as the reciprocal of the highest dilution of the sample that still causes agglutination ${ }^{21}$. The ethanol extract of $C$. mangga demonstrated high stimulation on antibody formation as compared to negative control $(\mathrm{P}<0.05)$. Surprisingly, ethanol extract at a dose of $400 \mathrm{mg} / \mathrm{kg} \mathrm{BW}$ displayed higher stimulation on antibody formation with an antibody titre of $6.33 \pm 0.12$ than levamisole as a positive control (antibody titre of $4.25 \pm 0.38$ ). Fig. -2 shows the dosedependent effect of ethanol extract of $C$. mangga on humoral antibody response.

Table-1: Effect of ethanol extract of Curcuma mangga rhizomes on Delayed-type hypersensitivity (DTH) response $($ Mean \pm SEM, $\mathrm{n}=5$ )

\begin{tabular}{clccc}
\hline \multirow{2}{*}{ No } & \multicolumn{2}{c}{ Sample } & \multicolumn{3}{c}{ Paw volume (ml) } \\
\cline { 3 - 5 } & & V0 & Vt & $\Delta \mathrm{V}$ \\
\hline 1 & CMC Na 0.5 \% & $0.54 \pm 0.03$ & $0.66 \pm 0.06$ & $0.12 \pm 0.04$ \\
2 & C. mangga at dose of $100 \mathrm{mg} / \mathrm{kg} \mathrm{BW}$ & $0.54 \pm 0.04$ & $0.93 \pm 0.06$ & $0.39 \pm 0.04^{*}$ \\
3 & C. mangga at dose of $200 \mathrm{mg} / \mathrm{kg} \mathrm{BW}$ & $0.46 \pm 0.03$ & $1.02 \pm 0.06$ & $0.56 \pm 0.07^{*}$ \\
4 & C. mangga at dose of $400 \mathrm{mg} / \mathrm{kg} \mathrm{BW}$ & $0.53 \pm 0.04$ & $1.24 \pm 0.11$ & $0.71 \pm 0.12 *$ \\
5 & Levamisole at dose of $25 \mathrm{mg} / \mathrm{kg} \mathrm{BW}$ & $0.56 \pm 0.02$ & $1.12 \pm 0.07$ & $0.56 \pm 0.04^{*}$ \\
\hline
\end{tabular}

Data were analyzed by one-way ANOVA, and followed by Tukey post hoc test.

$* P<0.05$ compared to the respective control

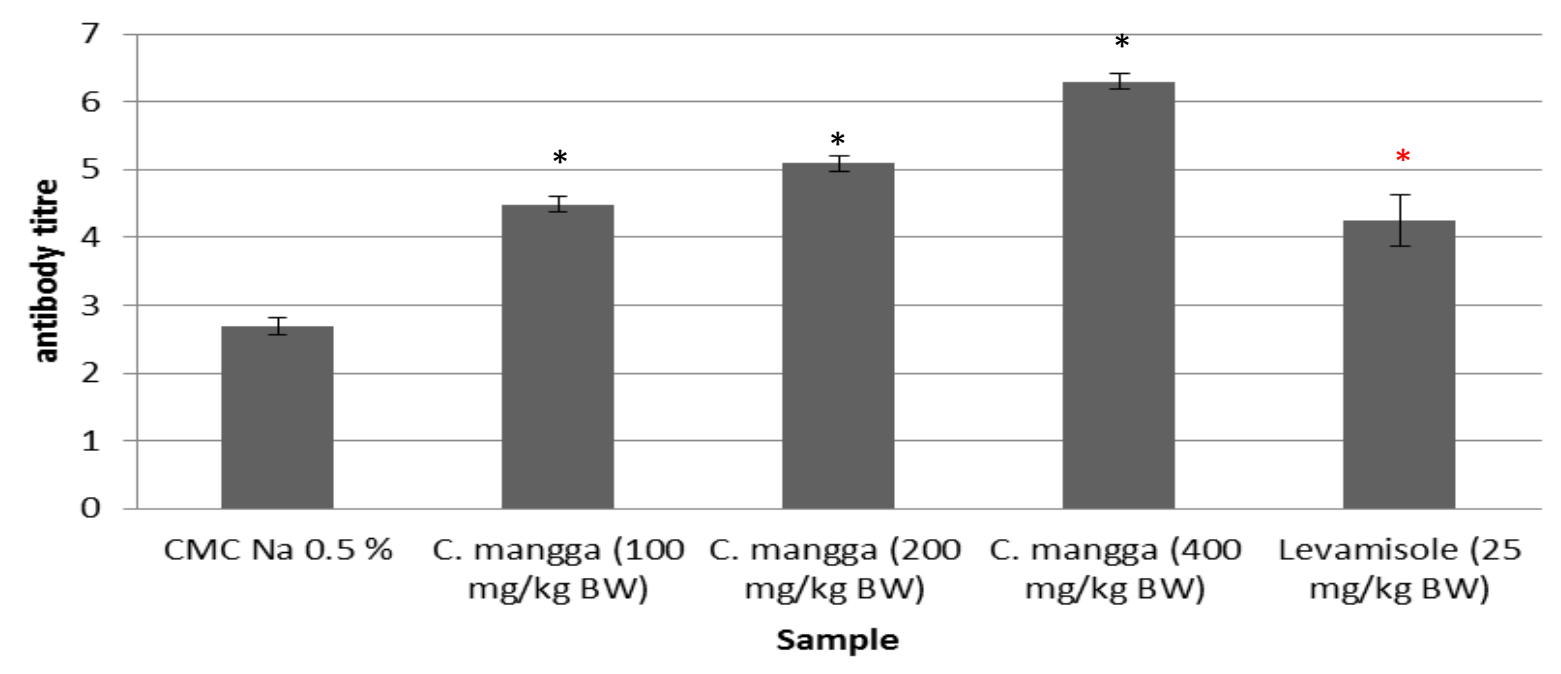

Fig.-2: Effect of ethanol extract of C. mangga on antibody titre of mice; Data are mean $\pm \mathrm{SEM}, \mathrm{n}=5,{ }^{*} \mathrm{P}<0.05$ significant with respective control

\section{CONCLUSION}

The UPLC analysis showed the presence of low amount of quercetin in ethanol extract of $C$. mangga rhizomes. The Curcuma mangga extract was able to modulate the cellular and humoral mediated immunity especially $\mathrm{T}$ lymphocytes activity and antibody formation. The extract at a dose of $400 \mathrm{mg} / \mathrm{kg}$ 
BW displayed the highest stimulant. Quercetin may be responsible for its immunostimulatory activity. Therefore, Curcuma mangga could be developed as an immunostimulatory agent. However, further studies are necessary to elaborate their effects on different lineages of immune responses.

\section{ACKNOWLEDGMENT}

This work was facilitated by University of Sumatera Utara through TALENTA research grant scheme with grant number of 175/UN5.2.3.1/PPM/KP-TALENTA USU/ 2017.

\section{REFERENCES}

1. B. Beutler, Mol. Immunol., 40, 845-59(2004), DOI: 10.1016/j.molimm.2003.10.005.

2. P.W. Dempsey, S.A. Vaidya, G. Cheng, Cell. Mol. Life. Sci., 60, 2604-21(2003), DOI: 10.1007/s00018-003-3180-y.

3. J. Nauta, Statistics in Clinical Vaccine Trials, Springer, Verlag Berlin Heidelberg, DOI: 10.1007/978-3-642-14691-6 2, c13. (2011).

4. S. Turvey, D.H. Broide, J. Allergy Clin. Immunol., 125, 24 (2010), DOI: 10.1016/j.jaci.2009.07.016.

5. U.S. Patil, A.V. Jaydeokar, D.D. Bandawane, Int. J. Pharm. Pharm. Sci., 4, 30-6(2012).

6. G.W. Hong, S.L. Hong, G.S. Lee, H. Yaacob, S.N.A. Malek, Asian Pac. J. Trop. Med., 9, 8-18(2016), DOI: 10.1016/j.apjtm.2015.12.003.

7. S.N.A. Malek, G.S. Lee, S.L. Hong, H. Yaacob, N.A. Wahab, et al., Molecules, 16, 4539-48(2011), DOI: $10.3390 /$ molecules16064539.

8. A.H. Karsono, O.M. Tandrasasmita, R.R. Tjandrawinata, Cancer Manag. Res., 6, 267-78(2014), DOI: $10.2147 / C M A R . S 61111$.

9. I. Jantan, M.A.M.Yassin, C.B. Chin, L.L. Chen, N.L. Sim, Pharm. Biol., 41, 392-97(2003), DOI: 10.1076/phbi.41.5.392.15941.

10. P. Ruangsang, S. Tewtrakul, W. Reanmongkol, J. Nat. Med., 64, 36(2010), DOI: 10.1007/s11418009-0365-1.

11. F. Abas, N.H. Lajis, K. Shaari, D.A. Israf, J. Stanslas, U.K. Yusuf, S.M. Raof, J. Nat. Prod., 68, 1090-93(2005), DOI: 10.1021/np0500171.

12. Y. Jiao, J. Wen, X. Yu, D. Zhang, Chin. J. Integr. Med., 7, 117-20(2001), DOI: 10.1007/BF02935017.

13. M. Materska, Pol J Food Nutr Sci., 58, 407-13(2008).

14. Yuandani, E. Suwarso, Asian J. Pharm. Clin. Res., 10, 148-50(2017), DOI: 10.22159/ajpcr.2017.v10i1.16196.

15. L.F. Ang, M.F. Yam, Y.T.T. Fung, P.H. Kiang, Y. Darwin, J. Pharmacopuncture, 17, 36-49(2014), DOI: $10.3831 /$ KPI.2014.17.035.

16. C.N. Nalini , A. Pyda, N. Ramalakshmi, K. K Bhatt, K. Sahini, Rasayan J. Chem., 10, 4(1500-1504), DOI: $10.7324 /$ RJC.2017.1041898

17. K. Mubashir, B.A. Ganai, K. Ghazanfar, S. Akbar, Int. Sch. Res. Notices.,DOI: 10.1155/2013/483646 (2013).

18. Y. Rajesh, K.D. Murli, Y. Nita, S. Rudraprabhu, Int. J. Biol. Med. Res., 2, 631-35(2011).

19. Roitt, Immunology. Gower Medical Publ., London. p 1-10 (1990).

20. N.H. Harun, A.W. Septama, I. Jantan, Asian Pac. J. Trop. Biomed., 5, 48-53(2015), DOI: 10.1016/S2221-1691(15)30170-2.

21. M. Thakur, P. Connellan, M.A. Deseo, C. Morris, V.K. Dixit, J. Evid. Based. Complementary Altern. Med., DOI: 10.1093/ecam/neq012 (2011).

[RJC-2097/2018] 